\title{
Impact of Foreign Direct Investment on Economic Growth: Empirical Evidence from Bangladesh
}

\author{
Afzalur Rahman ${ }^{1}$ \\ ${ }^{1}$ School of Business and Economics, Thompson Rivers University, Canada \\ Correspondence: Afzalur Rahman, School of Business and Economics, Thompson Rivers University, Kamloops, \\ BC, V2C 0C8, Canada. Tel: 1-778-257-5225. E-mail: afrahman@tru.ca
}

Received: November 19, 2014

Accepted: December 11, 2014

Online Published: January 25, 2015

doi:10.5539/ijef.v7n2p178

URL: http://dx.doi.org/10.5539/ijef.v7n2p178

\begin{abstract}
The core objective of this study is to evaluate the impact of Foreign Direct Investment (FDI) on the economic development of Bangladesh. To attain the objective, this paper has conducted statistical analyses of the relationships between FDI and its impact on selected macroeconomic indicators such as Gross Domestic Product, Inflation Rate, and Balance of Trade. The study has examined time series data over a period of fifteen years, from 1999 to 2013. Multiple Regression Analyses were utilized to measure the relationship between independent (FDI) and dependent variables (macroeconomic indicators). The results obtained in this research signify a negative correlation between FDI and economic growth and may be a concern for the government of Bangladesh. The government might focus on required reforms and policy implications to make foreign investment more beneficial.
\end{abstract}

Keywords: FDI, Bangladesh economy, economic growth, developing countries

\section{Background}

The impact of Foreign Direct Investment (FDI) on economic growth is a highly debated subject in academia. Some experts argue that there is a strong positive relationship between FDI and economic growth (Mengistu \& Adams, 2007). It has been suggested that FDI is vital to facilitate capital formation for developing countries, to transfer knowledge and technology, and to create employment which might have a direct affirmative impact on economic growth (Al-Iriani \& Al-Shamsi, 2009). Moreover, Sylwester (2005) claims that FDI influences domestic investment which further stimulates economic development of the host country.

On the other hand, some researchers indicate that FDI might have a negative impact on economic development of the recipient country (Hermes \& Lensink, 2003). The expatriation of profit by foreign firms risks the recipient country's balance of payments (BOP; Kentor, 1998). Fry (1999) argues that FDI has decreased the rate of national saving, domestic investment and, hence, economic growth in several developing nations.

A third view suggests that FDI can have a positive impact on the host country only if the host country has absorptive capacity in relation to the level of education, technology, infrastructure, human capacity, and political stability (Balasbubranyam, Mohammad, \& Sapsford, 1996; Sanchez-Robles, 2003).

From the above discussion, it is clear that experts are sharply divided on the impact of FDI on the economic development of the host country. This study attempts to determine whether FDI has a significant impact on economic growth by examining empirical evidence from Bangladesh.

\section{Country Overview: Bangladesh}

Bangladesh is an emerging country in South Asia that has the lowest paid labor force and lowest import tariff rate in the region (Foreign Investment, 2009). The garment industry in Bangladesh has a worldwide reputation, and its garment industry now accounts for more than $75 \%$ of total exports. Bangladesh has a strategic location advantage, situated between the vast emerging markets in South Asia and the fast growing markets in Southeast Asia. The middle class population in these regions is growing rapidly and its purchasing power is increasing.

Nevertheless, Bangladesh is a developing country with weak infrastructure (Rahman, 2008; Islam, 2003; Ahmed, 2005; Khan, 2007; Haque, 2007; Gupta, 1999). Within a developing nation, foreign assets are necessary to reduce the domestic savings gap, Balance of Payments (BOP) deficit, inflation rate, public deficit, foreign 
exchange gap, unemployment rate, and poverty level. Foreign assets also help to maintain steady growth in Gross Domestic Product (GDP) and Gross National Product (GNP), stable interest and exchange rates, and increased income per capita and Purchasing Power Parity (PPP;). Foreign investment is also vital for improving physical and human infrastructure and enabling access to technological know-how.

Realizing the importance of foreign investment, a new industrial policy was adopted by the government of Bangladesh (GOB) in 1999 to achieve the goal of rapid industrialization, by offering investment friendly incentives to foreign investors (Foreign Investment, 2009). This paper will investigate whether this 1999 industrial policy enabling the inflow of foreign direct investment has made a significant impact on the economic growth of Bangladesh over a period of 15 years, from 1999 to 2013.

\section{Purpose of the Study}

The objective of this study is to assess the effect of FDI on the economic growth of Bangladesh. This will be accomplished by conducting a historical and statistical analysis of the relationship between the trend of FDI inflow and its impact on selected macroeconomic indicators such as Gross Domestic Product, inflation rate, and balance of trade (BOT).

\section{Research Hypothesis}

As discussed earlier, experts are sharply divided on the impact of FDI on the economic development of the host country. The study is designed to address this disagreement with respect to the empirical evidence from Bangladesh. Thus this study will examine the following hypotheses:

H1: There is a strong positive relationship between FDI and GDP growth in Bangladesh.

$\mathrm{H} 2$ : There is a strong negative relationship between FDI and inflation rate in Bangladesh.

H3: There is a strong positive relationship between FDI and BOT in Bangladesh.

\section{Literature Review}

The central purpose of this section is to review the theories and research which are associated with the impact of FDI on economic growth. The section will begin by providing a definition of FDI. This will be followed by summarizing both the positive and negative relationships between FDI and economic growth, along with the arguments of those who claim that the effect of FDI is reliant on the absorptive capacity of the recipient country. The third part of this section discusses different types of FDI. The final part of this section will focus on the role of FDI in Bangladesh.

\subsection{Foreign Direct Investment (FDI)}

According to the International Monetary Fund (IMF), FDI refers to investments made to acquire a lasting interest in enterprises operating outside of the economy of the investor (Ridgeway, 2004). The IMF also considers an investment to be classified as FDI if the investor holds a partial ownership shareof at least $10 \%$ and exercises a significant amount of management control. This is similar to the way in which the Organization of Economic Co-operation and Development (OECD) defines FDI. According to the OECD (2012), "A foreign direct investment enterprise is an enterprise resident in one economy and in which an investor resident in another economy owns, either directly or indirectly, $10 \%$ or more of its voting power if it is incorporated or the equivalent for an unincorporated enterprise... An ownership of at least $10 \%$ of the voting power of the enterprise is regarded as the necessary evidence that the investor has sufficient influence to have an effective voice in its management

From the definitions of the IMF and OECD, one common requirement in defining an investment as FDI is that the investor's ownership must be at least $10 \%$, which is also a prerequisite for holding substantial control over the enterprise.

\subsection{Positive Effects of FDI on Economic Growth}

Modernization Theory states that FDI can positively contribute to economic growth in developing countries. According to Modernization Theory, the demand for capital formation in developing nations can be met by FDI through capital investment which can augment economic growth (Firebaugh, 1992). This concept is supported by Mello (1999) who concluded that foreign investment is an important element to fill the resource gap in many developing nations. For instant, FDI has enabled economic growth in South and East Asia by increasing capital formation (Fry, 1999). Moreover, Romer (1993) states that foreign investment is useful to build physical infrastructure such as roads and factories. Improved physical infrastructure, in turn, will increase the absorptive capacity of the host country, which may attract further FDI. 
Modernization Theory also suggests that FDI transfers knowledge, technologies, managerial skills, and ideas which can contribute to the economic development of the recipient country (Mengistu \& Adams, 2007). Endorsing this idea, Borensztien et al. (1998) argue that foreign investment enhances economic growth by transferring technology and knowledge to developing countries. Evidence also shows that foreign investment encourages domestic investment. In a study of 66 developing countries, Makki and Somwaru (2004) found that FDI stimulated domestic investment, which further advanced economic growth. Other research carried out by Agosin and Mayer (2000) claimed that foreign investment positively influenced domestic investment in Asian countries.

Baliamoune-Lutz (2004) found that that foreign investment has a positive impact on economic growth through improving exports. A similar view is shared by Kabir (2007), who argues that FDI increases the amount of exports and thus enhances foreign currency earnings, which can be used to pay external debts. Zhang (2006) also found that foreign investment has enhanced the economic growth of China by raising its export volume.

Furthermore, FDI has been shown to increase GDP, GNP, and PPP (Islam, 2003; Ahmed, 2005; Khan, 2007; Haque, 2007; Gupta, 1999; Kabir, 2007). FDI also plays a role in reducing the domestic savings gap, foreign exchange gap, BOP deficit, unemployment rate, inflation rate, and level of poverty. FDI has also been linked with introducing corporate social responsibility, diversifying exports, and developing financial institutions

\subsection{Negative Effects of FDI on Economic Growth}

Dependency Theory claims that foreign investment has a negative impact on the economic development of the recipient country (Dutt, 1997). This theory is supported by Brecher and Diaz-Alejandro (1977) where they argue that FDI may have a negative effect on the economic growth of the host country if the FDI-financed companies repatriate excessive profits to the parent country. This circumstance is known as repatriation of profit, which adversely affects the BOP of the host country (Brecher \& Diaz-Alejandro, 1977).

Experts assert that FDI has an adverse effect on economic development by crowding out domestic investment. For instant, in a study on eleven Central and Eastern European countries, Eller, Haiss, and Steiner (2005) found that foreign investment crowded out domestic capital. In another study, Bornschier and Chase-Dunn (1985) concluded that in addition to crowded out domestic investment, FDI would be responsible for creating a monopoly. Moreover, Quazi (2004) states that FDI might have a negative impact on the host country due to capital flight, which is the outflow of domestic capital, resulting in an adverse effect on the country's current account and foreign exchange account.

FDI increases the host country's imports because FDI-financed companies often need high-tech capital machinery and intermediate goods that are often not available in the host country (Rahman, 2008). Increasing imports may have a negative impact on economic growth due to the resulting trade deficit (Fry, 1999). Biersteker (1978) and Helleiner (1989) are skeptics about the role of FDI on the economic growth of developing nations. They argue that FDI is a mechanism for exploiting and controlling developing countries by western industrialized nations.

\subsection{The Effect of FDI Is Reliant on the Absorptive Capacity of the Recipient Country}

A third view claims that the impact of FDI on economic growth depends on the absorptive capacity of the recipient country. In this regard, Buckley, Clegg and Wang (2002) state that FDI would be helpful to economic development if the economic, political, and social conditions of the host country are complimentary. However, if a country does not have the appropriate business environment to benefit from a positive spillover effect from the presence of foreign firms (i.e., have the appropriate business environment to facilitate transfer of technological and managerial skills), FDI may have negative impact on economic development (Toulaboe, Terry, \& Johansen, 2009). For instance, the impact of FDI on economic growth would be more significant in East Asian and Latin American countries than in sub-Saharan African countries because East Asian and Latin America have relatively higher levels of development compared to sub-Saharan Africa (Toulaboe, Terry, \& Johansen, 2009).

The benefit from foreign investment is not automatic. The advantages of FDI depend on skilled human resources, improved technology, developed infrastructure, open trade policy, macroeconomic and institutional reforms, and FDI friendly policies (Borensztein et al., 1998; Makki \& Somwaru, 2004). For example, in a study of 46 countries, Balasbubranyam, Mohammad, and Sapsford (1996) found that FDI had a stronger impact on economic growth when the host countries had a more highly educated workforce. In another study, Sun (1998) found that a liberalized trade policy stimulated the effect of foreign investment on the economic growth of China through capital formation, raising export volume, and reducing the unemployment rate. Corruption and lack of transparency, on the other hand, tend to discourage foreign investment (Kaufmann \& Wei, 1999). 


\section{Types of FDI}

FDI can be classified into five different types which include: (1) greenfield investment, (2) merger or acquisition, (3) joint venture, (4) horizontal FDI, and (5) vertical FDI (Ball \& McCulloch, 1999). They are discussed in the following sections:

\subsection{Greenfield Investment}

A company that wishes to own a foreign subsidiary outright may start from a greenfield investment by building new facilities or expanding existing facilities (Ball \& McCulloch, 1999). The establishment of industrial plants and facilities at export processing zones (EPZs) are examples of greenfield investment in Bangladesh.

\subsection{Merger or Acquisition}

A merger or acquisition occurs when a foreign firm purchases the existing assets of a local firm (Ball \& McCulloch, 1999). For example, in 2004, a major global telecommunications firm called Orascom purchased $100 \%$ of ShebaTelecom (Pvt.) Ltd. in Bangladesh. This acquisition was used to start a business known as "BanglaLink," a wholly-owned subsidiary of Orascom.

\subsection{Joint Venture (JV)}

A joint venture can be established in several ways. A joint venture can be established when an international company joins with a local company (or with another international company) to form a corporate entity. Alternatively, the international company could join with the government of the country of investment to form a corporate entity (Ball \& McCulloch, 1999). For example, GrameenPhone (GP) in Bangladesh is a JV formed by Telenor of Norway and Grameen Telecom of Bangladesh.

\subsection{Horizontal FDI}

Horizontal FDI refers to the situation where a company invests in the same type of industry abroad that they are involved in at home (Foreign Direct Investment, 2009). In the JV example described above, Telenorwas a major competitor in the telecommunications market in Norway, prior to entering the Bangladesh telecommunications market by forming a JV with local firm Grameen Telecom.

\subsection{Vertical FDI}

Vertical FDI has two forms: (1) Backward vertical FDI involves investing in an industry which provides inputs for the investing firm's domestic production; and (2) Forward vertical FDI involves investing in an industry which sells the output of the investing firm's domestic production.

\section{FDI in Bangladesh}

As discussed before, FDI can help to fill the resource gap in a developing country. As a developing nation, Bangladesh has long been aware of the necessity and importance of foreign investment. Immediately after its independence from Pakistan in 1971, Bangladesh began trying to attract FDI for purposes of capital formation and transfer of technology and knowledge. The inflow of FDI has increased significantly since 1999, when the new industrial policy was adopted by the government of Bangladesh.

The Board of Investment (BOI) in Bangladesh, which was created for speedy implementation of new industrial projects, provides a wide range of services to foreign investors including infrastructure facilities, import and export facilities, dispute resolution for foreign investors, and pre-investment counseling (Foreign Investment, 2009). BOI also provides courtesy services to visiting foreign investors such as reception at the airport, hotel booking, and transportation arrangements.

FDI in Bangladesh is encouraged in areas such as energy and power infrastructure, as well as industries such as telecommunications, computers, aircraft and motor parts, textiles, agriculture, and pharmaceuticals (Foreign Investment, 2009). While these are preferred sectors, foreign investors are welcome to invest any sector of their choice except the "reserved industries" such as arms and ammunition, forest plantation, nuclear energy, and printing currency notes. In all sectors except for the reserved industries, Bangladesh provides non-discriminatory treatment between foreign and local investors.

In a wide variety of respects, foreign investors enjoy the same benefits as local investors, including a tax holiday, payment of royalties, and technical know-how fees (Foreign Investment, 2009). Foreign investors also enjoy 100\% foreign equity and full repatriation of profits. In addition to the FDI-friendly policy, the GOB has established EPZs to provide lucrative incentives to the foreign investors.

During the last fifteen years, the amount of FDI inflow in Bangladesh has increased from \$394 million in 1999 to $\$ 1.73$ billion in 2013 (BB, 2013). Nevertheless, the amount of FDI in Bangladesh (population of 150 million) 
is still disproportionately low compared to neighboring India (population of 1.2 billion). In 2013, India received \$28 billion FDI (UNCTAD, 2013). Factors behind of the limited FDI inflow in Bangladesh include political instability, inadequate infrastructure, inefficient bureaucracy, widespread corruption, unskilled labor force, and a slow moving privatization process (Rahman, 2008).

The purpose of this research, however, is not to find and analyze the factors which are limiting FDI inflow in Bangladesh. Rather, this study investigates whether FDI has an impact on economic development in Bangladesh by analyzing historical data from 1999 to 2013.

\section{Methodology}

This research examines time series data over a period of fifteen years from 1999 to 2013 (see data set in the Appendix). To test the three hypotheses, multiple regression analysis was conducted using FDI inflow as the independent variable, and GDP, CPI inflation, and BOT as the three dependent variables.

The historical data (from 1999 to 2013) of FDI inflow, GDP growth, CPI inflation, and BOT, were collected from publications issued by the Bangladesh Bank (BB), the country's central bank responsible for reporting FDI and macroeconomic data. BB uses a survey reporting system and book valuation system to collect and present its primary data (Methodological, 2010). Since BB is the source of both FDI inflow data and macroeconomic data, any inconsistencies in generating data will be minimized.

\section{Statistical Interpretation}

The relationships between FDI and GDP growth rate, FDI and Inflation rate, and FDI and Balance of Trade were analyzed based on the time series data from 1999 to 2013.

\subsection{FDI and GDP Growth}

A Pearson correlation was used to describe the strength and direction of the linear relationship between independent (FDI) and dependent (GDP growth) variable. The Pearson correlation was .38, indicating a moderate positive correlation between FDI and GDP growth, but the significance level was .08, suggesting that the relationship between FDI and GDP growth is not statistically significant.

\subsection{FDI and Inflation Rate}

The correlation coefficient is .573 , suggesting a strong positive relationship between FDI and Inflation rate $(\mathrm{p}=.013)$. The $\mathrm{R}$ square is .328 , indicating that $32.8 \%$ of the variance in Inflation rate is explained by the variance in the amount of FDI inflow.

\subsection{FDI and Balance of Trade (BOT)}

There is a strong negative relationship between FDI and BOT which is supported by large and significant correlation coefficient of .697 The $\mathrm{R}$ square is .486 , thus, $48.6 \%$ of the variance in the BOT is explained by the variance in the amount of FDI inflow.

\section{Discussion of the Findings}

The statistical findings exhibited an insignificant positive correlation between FDI and GDP growth, a strong positive correlation between FDI and inflation rate, and a strong negative correlation between FDI and BOT. Therefore, the results obtained in this research suggest that growth in FDI has not been associated with positive economic growth in Bangladesh. FDI was linked with increases in the inflation rate and a negative trade balance. As discussed before, higher inflation rate reduces the purchasing power of people and has been blamed for economic stagnation. Additionally, a negative trade balance occurs when a country's imports are higher than exports and this creates a resource gap for developing nations. In contrast, FDI appears to have a small positive, but not statistically significant, impact on GDP growth.

Since this research found negative correlations between FDI and two out of the three macroeconomic indicators, these results may be a concern for the government of Bangladesh. A low-capital country like Bangladesh cannot ignore the importance of foreign investment for sustainable growth. Evidence suggests that the impact of FDI on economic growth is reliant on the absorptive capacities of the recipient country, which takes into account factors such as skilled human resources, technology, infrastructure, trade policy, institutional reform, and political conditions (Borensztein et al., 1998; Makki \& Somwaru, 2004).

There are number of factors which are responsible for hindering positive outcomes from foreign investment in Bangladesh, such as an unskilled labor force, inadequate infrastructure, a slow moving privatization process, inefficient bureaucracy, political instability, and recurring natural disasters (Rahman, 2008). Corruption and lack of transparency further increase the difficulty of doing businesses in Bangladesh (Transparency, 2010). Like 
other least developed nations, Bangladesh's comparative advantage lies on the basic factors of production such as low-cost labor. However, the country should improve the efficiency and effectiveness of its labor market by creating educated and skilled labor force. A competent labor force is considered as an advanced factor of production which is a prerequisite for industrialization and economic augmentation. Moreover, required reform and policy implications would advance the functionality of foreign investment in Bangladesh. The benefits of FDI are not automatic. To make the FDI beneficial, the government of Bangladesh must improve the absorptive capacity of the country such as educated labor force, strong infrastructure, interrupted supply of utilities, investment friendly policy, advanced technology, and political stability.

\section{Recommendations for Future Research}

The result of this study would be useful to foreign investors and development organizations seeking to better understand the role of FDI in Bangladesh. The negative impact of FDI on economic growth may raise concerns among international organizations such as the United Nations (UN), World Bank (WB), and International Monetary Fund (IMF), which are working to promote the macroeconomic well-being of developing countries. These organizations may push the government of Bangladesh to take the steps that are necessary to make future foreign investment advantageous.

Future research should be focused on finding a causal relationship between FDI and economic growth in Bangladesh. It is recommended that future research include other macroeconomic indicators (such as unemployment rate, gross national product, purchasing power parity, poverty level, and foreign exchange rate), which may help to better explain the effect of foreign investment on the economic growth of Bangladesh.

\section{References}

Agosin, M., \& Mayer, R. (2000). Foreign direct investment: Does it crowd in domestic investment? United Nations Conference on Trade and Development Working Paper No. 146, Geneva, Switzerland.

Ahmed, I. (2005). Aid and policy reforms in Bangladesh. Centre for Policy Dialogue, Dhaka, July, 2005.

Al-Iriani, M., \& Al-Shamsi, F. (2009). Foreign direct investment and economic growth in the GCC countries: A causality investigation using heterogeneous panel analysis.

Balasbubranyam, V. N., Mohammad, S., \& Sapsford, D. (1996). Foreign direct investment and growth in ED and IS countries. Economic Journal, 106(1), 92-105. http://dx.doi.org/10.2307/2234933

Baliamoune-Lutz, M. N. (2004). Does FDI contribute to economic growth? Business Economics, 39(2), 49.

Ball, D. A., \& McCulloch, W. H. (1999). Glossary. International Business: The challenge of global competition (7th ed.). The McGraw-Hill Companies.

Bengoa, M., \& Sanchez-Robles, B. (2003). Foreign direct investment, economic freedom and growth: new evidence from Latin America. European Journal of Political Economy, 19, 529-545. http://dx.doi.org/10.1016/S0176-2680(03)00011-9

Biersteker, T. (1978). Distortion or Development: Contending perspective on the multinational corporation. Cambridge, MA: MIT Press.

Borensztein, E., Gregorio, J. D., \& Lee, J. W. (1998). How does foreign direct investment affect economic growth? Journal of International Economic, 45, 115-135. http://dx.doi.org/10.1016/S0022-1996(97)00033-0

Bornschier, V., \& Chase-Dunn, C. K. (1985). Transactional corporations and underdevelopment. New York: Praeger.

Brecher, R. A., \& Diaz-Alejandro, C. F. (1977). Tariffs, Foreign Capital, and Immiserizing Growth. Journal of International Economics, 7, 317-322. http://dx.doi.org/10.1016/0022-1996(77)90048-4

Buckley, P. J., Clegg, J., \& Wang, C. (2002). The impact of inward FDI on the performance of Chinese manufacturing firms. Journal of International Business Studies, 33(4), 637-655. http://dx.doi.org/10.1057/palgrave.jibs.8491037

Chase-Dunn, C. (1975). The effects of international economics dependence on development inequality: A cross national study. American Sociological Review, 40, 720-738. http://dx.doi.org/10.2307/2094176

Creswell, J. W. (2009). The selection of a research design. Research design: Qualitative, Quantitative, and Mixed methods approaches (3rd ed.). Sage Publications, Inc.: Thousands Oaks, CA.

Dutt, A. K. (1997). The pattern of foreign direct investment and economic growth. World Development, 25(11), 
1925-1936. http://dx.doi.org/10.1016/S0305-750X(97)00081-8

Eller, M., Haiss, P., \& Steiner, K. (2005). Foreign direct investment in the financial sector: The engine of growth for central and eastern Europe? EuropInstitut Working Paper No. 69, Vienna University of Economics and Business Administration. http://dx.doi.org/10.2139/ssrn.875614

Firebaugh, G. (1992). Growth Effects of Foreign and Domestic Investment. American Journal of Sociology, 105-130. http://dx.doi.org/10.1086/229970

$\begin{array}{llll}\text { Foreign } & \text { Investment. } & \text { (2009). } & \text { Retrieved }\end{array}$ http://www.iptu.co.uk/content/pdfs/BANGLADESH\%20RELATED\%20ARTICLES/foreigninvestment.pdf

Fry, M. (1999). Some lessons for South Asia from developing country experience with foreign direct investment. The World Bank, 1999, Washington D.C.

Growth: Trends and Cycles. (1997). The Economist: Guide to economic indicators. New York: John Wiley and Sons, Inc.

Gupta, K. L. (1999). Foreign assistance and development in Bangladesh. Foreign Aid: New Perspectives. Retrieved from http://books.google.com/books?id=5Tw6AkT5HsMC\&lpg=PA211\&ots=c 0by62n R\&dq=bangladesh\%3A $\% 20$ sources $\% 20$ of $\% 20$ foreign $\% 20$ aid\&pg $=\mathrm{PA} 211 \mathrm{\#}=$ =onepage $\& \mathrm{q}=\& \mathrm{f}=$ false

Haque, A. N. (2007). Aid Addiction. The Daily Star, 5. Retrieved from http://www.thedailystar.net/2007/07/29/d70729020427.htm

Helleiner, G. (1989). Transnational corporations and direct foreign investment. In H. Chenery \& T. N. Srinivasan (Eds.), Handbook of Development Economics (pp. 1441-1480). Elsevier Science Publishers B.V. http://dx.doi.org/10.1016/S1573-4471(89)02014-0

Hermes, N., \& Lensink, R. (2003). Foreign direct investment, financial development and economic growth. Journal of Development Studies, 40(1), 142-153. http://dx.doi.org/10.1080/00220380412331293707

Islam, A. M (2003). A preliminary analysis of the U.S. foreign aid to Bangladesh. Retrieved from http://www.ser.tcu.edu/2003-Pro/SEP\%202003\%20Islam\%201-8.pdf

Kabir, R. (2007). Foreign direct investment and sustainable growth: A case study on Bangladesh. A thesis submitted to the faculty of Emory College of Emory University. Department of Economics. Retrieved from http://www.docstoc.com/docs/2380675/Foreign-Direct-Investment-and-Sustainable-Growth-A-Case-Studyon

Kaufmann, D., \& Wei, S. (1999). Does grease money speed up the wheels of commerce? Policy research working paper series 2254, The World Bank, Washington D. C. http://dx.doi.org/10.5089/9781451848557.001

Kentor, J. (1998). The long-term effects of foreign investment dependence on economic growth. American Journal of Sociology, 103(4), 1024-1046. http://dx.doi.org/10.1086/231295

Khan, S. (2007). Aid flow to Bangladesh and the question of accountability of CSOs at national level to the people they serve. Retrieved from http://www.unnayan.org/news/files/CSO.pdf

Makki, S., \& Somwaru, A. (2004). Impact of foreign direct investment and trade on economic growth: Evidence from developing countries. American Journal of Agricultural Economics, 86(3), 795-801. http://dx.doi.org/10.1111/j.0002-9092.2004.00627.x

Mello, D. L. R. Jr. (1999). Foreign direct investment-led growth: Evidence from time series and panel data. Oxford Economic Papers, 51(1), 133-151. http://dx.doi.org/10.1093/oep/51.1.133

Mengistu, B., \& Adams, S. (2007). Foreign direct investment, governance and economic development in developing countries. The Journal of Social, Political, and Economic Studies, 32(2), 223.

Methodological Notes. (2010). World Investment Report 2010. Retrieved from http://www.unctad.org/sections/dite_dir/docs/wir2010meth_en.pdf

OECD. (2012). Glossary of foreign direct investment terms and definitions. Retrieved from http://www.oecd.org/investment/investmentfordevelopment/2487495.pdf

Quazi, R. M. (2004). Foreign aid and capital flight: A case study of Bangladesh. Journal of the Asia Pacific Economy, 9(3), 370-393. http://dx.doi.org/10.1080/1354786042000272008

Rahman, K. M. A. (2008). Globalization and the climate of Foreign Direct Investment: A case study for 


\section{Bangladesh. Journal of Money, Investment and Banking.}

Ridgeway, A. (2004). Definition of foreign direct investment (FDI) terms. Issues paper 20, Statistic Canada. Retrieved from http://www.imf.org/external/np/sta/bop/pdf/diteg20.pdf

Romer, P. (1993). Idea gaps and object gaps in economic development. Journal of Monetary Economics, 32(3), 543-573. http://dx.doi.org/10.1016/0304-3932(93)90029-F

Salvin, S. L. (1996). Gross Domestic Product. Macroeconomic (4th ed.). Times Mirror Higher Education Group.

Samuelson, P. A., \& Nordhaus, W. D. (2001). Glossary of terms. Economics (17th ed.). New York, NY: The McGraw-Hill Companies.

Sun, H. (1998). Macro-economic impact of direct foreign investments in China: 1979-1996. Ashgate Publishing Company.

Sylwester, K. (2005). Foreign direct investment, growth, and income inequality in Less Developed Countries. International Review of Applied Economics, 19(3), 289. http://dx.doi.org/10.1080/02692170500119748

Toulaboe, D., Terry, R., \& Johansen, T. (2009). Foreign direct investment and economic growth in developing countries. Retrieved from http://www.ser.tcu.edu/2009/SER2009\%20Toulaboe\%20et\%20al\%20155-170.pdf

Transparency International. (2010). Corruption Perception Index 2010. Retrieved from http://www.ti-bangladesh.org/CPI/CPI2010/5_CPI2010_table_sources_2010-10-20\%5B1\%5D-latest.pdf

UNCTAD. (2013). World Investment Report. Retrieved from http://unctad.org/en/publicationslibrary/wir2013_en.pdf

Zhang, K. H. (2006). Foreign direct investment and economic growth in China: A panel data study for 19922004. Retrieved from http://faculty.washington.edu/karyiu/confer/beijing06/papers/zhang.pdf

\section{Appendix A}

Table A1. Time series data of Bangladesh (1999-2013): FDI inflow and selected macroeconomic indicators

\begin{tabular}{ccccc}
\hline Year & $\begin{array}{c}\text { FDI Inflow } \\
\text { (in million of US\$) }\end{array}$ & GDP Growth Rate (\%) & $\begin{array}{c}\text { CPI Inflation } \\
\text { Rate (\%) }\end{array}$ & $\begin{array}{c}\text { Balance of Trade } \\
\text { (in million of US\$) }\end{array}$ \\
\hline 1999 & 394 & 4.9 & 7.1 & -1934 \\
2000 & 383 & 5.9 & 2.8 & -1865 \\
2001 & 564 & 5.3 & 1.9 & -2011 \\
2002 & 401 & 4.4 & 2.8 & -1768 \\
2003 & 379 & 5.3 & 4.4 & -2215 \\
2004 & 284 & 6.3 & 5.8 & -2319 \\
2005 & 804 & 6.0 & 6.5 & -3297 \\
2006 & 745 & 6.6 & 7.2 & -2889 \\
2007 & 793 & 6.4 & 7.2 & -3458 \\
2008 & 769 & 6.2 & 9.9 & -5330 \\
2009 & 961 & 5.7 & 6.7 & -4710 \\
2010 & 913 & 6.1 & 7.3 & -5155 \\
2011 & 779 & 6.7 & 8.8 & -9935 \\
2012 & 1195 & 6.2 & 10.6 & -9320 \\
2013 & 1731 & 6.0 & 7.7 & -7010 \\
\hline
\end{tabular}

Sources: Bangladesh Bank Annual Reports 2000, 2003, 2007, 2013, and 2014. FDI Inflow (2013), GDP Growth Rate (2007 and 2014), Inflation Rate (2007 and 2014), Balance of Trade (2000, 2003, and 2013).

Website: http://www.bb.org.bd/pub/publictn.php

\section{Copyrights}

Copyright for this article is retained by the author(s), with first publication rights granted to the journal.

This is an open-access article distributed under the terms and conditions of the Creative Commons Attribution license (http://creativecommons.org/licenses/by/3.0/). 